\title{
INCLUSION, LEGISLATION AND PRACTICE: EDUCATING STUDENTS WITH DISABILITIES - THE AUSTRALIAN AND LATVIAN EXPERIENCES
}

\author{
Ilga Prudņikova \\ Rezekne Higher Education Institution, Latvia \\ Ilona Bruveris \\ University of Notre Dame, Australia
}

\begin{abstract}
In Australia and Latvia the inclusion debate has changed the face of education. This change has been brought about by legislative edicts, challenges to traditions which segregate students and by confronting teacher beliefs. This article explores the experiences of the education system in Australian, specifically the state of New South Wales (NSW), in addressing inclusion. Parallels between the Australian and Latvian experiences are identified. Finally the retreat by the NSW system away from the confusion surrounding the use of the term inclusion to the concept of every student, every school is detailed.
\end{abstract}

Keywords: inclusive education, students with disabilities, educational policy, professional learning.

\section{Introduction}

Inclusive education is based on concepts of social justice and equity but how these terms are understood and then manifested in the provision of educational services for each and every student varies across nations and education systems. The waters are muddied by the fact that the term inclusion attracts a plethora of meanings (Lindsay, 2007; Kavale \& Forness, 2000). It has been used to discuss social justice, human rights (Lindsay, 2007) or as a way of building democracy (Villa, Thousand, Stainback \& Stainback, 1992). Slee is disappointed that it has moved away from its original meaning which rejected the notion of medical or psychological labels to explain educational differences (as cited in Miles \& Singal, 2010). With such complexity, how then do educational systems address inclusion? Where do they start and why? In the responses of NSW and Latvia it is possible to see the impact of "big picture" factors such as legislature, existing traditions, teacher beliefs and professional learning. These are elements that education systems can incorporate or address. Legislature from international declarations and conventions is crucial to the process of bringing about change. Traditions that have led to segregation, such as ways of defining disability and service provision, need to be confronted. Similarly teacher belief systems need to be challenged. The governments and education systems of both countries are engaged in these processes.

The purpose of the research was to analyse the NSW approach to inclusive schooling for students with disabilities to identify what impact the inclusive 
schooling movement has had on NSW education department initiatives and directions. The Latvian experience is used as a comparison to determine what common elements are impacting on the way systems address inclusion. Questions that informed the review were the following:

- What is the role of legislative edicts in both jurisdictions?

- How do traditions within the NSW system impact on inclusion?

- If teacher beliefs, skills and knowledge concerning the education of students with disabilities impact on the change process, in what ways do NSW Departmental initiatives address these? How can teacher beliefs be altered?

- Is there an alternative to inclusion that would support the concept of education for all without the confusion that can sometimes arise from use of the term inclusion?

The methods used were: the review of legislature and policy documents relating to inclusive schooling and education for all in both NSW, Australia and Latvia; summation of major initiatives undertaken by the NSW state education system in response to inclusive schooling for students with disabilities.

\section{NSW and Latvian education systems}

The NSW state education system (Department of Education and Communities or DEC) is a large and complex one as testified by the fact that currently there are more than 740,000 students of whom $27 \%$ have a language background other than English, 5.5\% are of Aboriginal or Torres Strait Islander descent and $2.0 \%$ are refugees. More than $76 \%$ of students with confirmed disability are enrolled in public schools: 90,000 students (12\%) have a disability or additional needs such a learning difficulties or behaviour disorders; $77 \%$ of students with disability, learning or behaviour difficulty are enrolled in regular schools. These students are accommodated in 2,200 schools, taught and supported by 95,000 teachers and other employees (NSW. Department of Education and Communities, 2011).

In contrast in Latvia, in the 2013/2014 school year, there were 10,865 students with disabilities enrolled in schools. Of these, 5805 attended a special school and 5060 were enrolled in regular schools. Students with special needs made up $5.49 \%$ of the total school population (Ministry of Education and Science data). It is obvious that the NSW system has the advantages of size more funding which means more services and initiatives, more choice. However it also has the disadvantages. Changing traditional ways of identifying, placing and teaching students with disabilities means changing teacher beliefs, something which is difficult to achieve in a large and geographically dispersed school system. Similarly membership of the European Union helps Latvia, a country with a population of 1988.4 (Central Statistical Bureau of Latvia data), counteract the impact of being a small nation. 


\section{Impact of legislative edicts}

Both education systems point to the importance of legislature for the change process. As Skrtic argues, schools and systems need external pressure in order to bring about change. Education systems across the world have seen the impact of a range of international declarations and conventions (Skrtic, 1991). Declarations that have influenced governments to develop national legislature have included: the UNESCO Universal Declaration of Human Rights 1948; the Convention against Discrimination in Education 1980; the Convention on the Rights of the Child 1989; the UNESCO Salamanca Statement and Framework for Action in Special Needs Education 1994; the UN Convention on the Rights of Persons with Disabilities 2006 and the UNESCO Policy Guidelines on Inclusion in Education 2009. The Latvian education system has responded not only to these, but also to the Education for All (EFA) movement originating at the World Education Forum in Jomtien, Thailand (Prudnikova, 2012). The 1994 Salamanca World Conference on Special Needs Education (UNESCO 1994) followed on from this, endorsing inclusive education arguing that regular schools with an inclusive orientation are the most effective means of changing discriminatory attitudes and achieving education for all (The Salamanca Statement and Framework for Action on Special Needs Education, 1994).

These conventions have led to legislature and regulations in Latvia that both describe and prescribe learning opportunities for all children including those with disabilities. The legislature has included: The Latvian Constitution of the Republic (The Latvian Constitution of the Republic, 1922/2010) which affirms that everyone has the right to an education; The Children's Rights Defence Law (The Children's Rights Defence Law, 1998) that states that children have the right to living conditions which support their physical and mental development; The Education Act (The Education Act, 1998) which guarantees access to special education programs for students with special needs; the General Education Law (General Education Law, 1999) which stipulates that students with special needs can receive support in any school setting and that they must have an individualised learning plan. Individualised education plans are a common feature of services for students with disabilities across jurisdictions. This leads to a quandary on the road to inclusion as they are also perceived by many regular class teachers as part of the reason why the student with disabilities should be educated in a special setting.

As well Cabinet Ministers' Regulations (2003-2010), which deal with turning laws into practice, specified that exemplary special education settings would be granted the status of Centre of Development for students with special needs and established networks among integrating schools to support these students. These actions reflect an important element of the Salamanca Declaration, which is the need to establish educational support systems for students with special needs to facilitate their inclusion. A similar move has taken 
place in NSW where special schools are being re-badged as Centres of Expertise as part of their "Every student, every school" initiative which is discussed later.

Finally, the Education Development Guidelines for 2014 - 2020 (The Education Development Guidelines for 2014 - 2020, 2014) address a broad spectrum of special education issues including the educational rights of students with disabilities, the need for a solutions-based approach and the role of society in securing the inclusion of students with special needs. This document indicates a move to focusing on solutions not just the disability, an important aspect for inclusion and one that will be examined in more detail with respect to the NSW system.

Within the NSW context, one of the most formative conventions has been the UN Convention on the Rights of Persons with Disabilities which has led to The National Disability Strategy 2010-2020 (which aims to identify and remove barriers to services for people with a disability) and the National Disability Insurance Scheme Act 2013 (which provides for the National Disability Insurance Scheme in Australia and supports the independence and social and economic participation of people with disability).

The NSW Department of Education and Communities is also bound by, at a national level, the Disability Discrimination Act 1992 and the Disability Standards for Education 2005. The standards cover enrolment, parent choice, access and participation, curriculum development, accreditation and delivery, student support services, elimination of harassment and victimization. The Standards require schools to treat students with disabilities on the same basis as students without disability and include obligations for making reasonable adjustments to student's learning program and /or learning environment. Parents and, where appropriate, students with disabilities must be consulted on the personal adjustments that will be provided. It should be noted here that the term "reasonable adjustments", however, allows schools to decline enrolments if such an enrolment would create undue hardships or interfere with the learning of other students.

At a state (NSW) level the Department and its schools are also bound by the Anti-discrimination Act 1997, the Ombudsman Act 1974 and the Disability Inclusion Act 2014.

These acts, and the theories associated with their institution, have had a significant impact on the services provided by the Department over the years as it has moved from a disability category focus prevalent in the 1960-1970s to the current functional needs focus, where personalised learning adjustments are key. This has seen the Department and its schools, leaders, teachers and support staff move from segregation, to integration in the 1980s, inclusion in the 1990s and leading to a focus on diversity in the 2000 s. 


\section{Challenging Traditions}

Traditions, such as those associated with student placement or the range of support services, impact on how teachers view students with special needs and how they view their own ability to meet these needs. The determination of disability (the who, how and what) is an important element both for accessing educational options and for the process of making schools inclusive and education systems have traditionally relied on a medical model.

In Latvia special education support is enshrined in the General Education Law in Article 3 (The General Education Law, 1999). Article 1 of the Education Act specifies the range of people who require the support of special education (The Education Act, 1998). It states that special education services create the opportunities and conditions for students with special needs to be able to access any educational institution and to receive an appropriate education which takes into account their health needs, capabilities and level of development, all the while providing educational, psychological and medical adjustments, preparing them for work and life in the community. The term, "special needs" is defined by law in Article 1 as being ,a need for support and rehabilitation which, when provided, facilitates the student's access to the curriculum, while taking into account the state of the student's health, his/her capabilities and level of development" (The Amendments to the General Education Act, 2011).

With such a broad definition of special needs, it is the role of the State Pedagogical Medical Commission or local government pedagogical medical commissions under the jurisdiction of the Cabinet of Ministers (The General Education Law, 1999) to ensure that students with special needs can access a quality education based on equality and equal rights. These commissions determine who meets the special needs criteria and can access additional or different services.

In NSW, the placement of students in special classes or even access to additional support in a regular setting has been, until the 2000s, dependent upon a medical model of defining disability. As the medical model places an emphasis on deficits, there has been a gradual move, especially amongst educators, towards a way of determining need without linking it to a deficit. As Van Swet, Wichers-Bots and Brown state "The ways in which individuals with disabilities are viewed has been an evolving global debate. The World Health Organization (WHO) revised its International Classification of Functioning, Disability and Health (ICF) in 2001 to consider the impact rather than the cause of the universal human experience of disability" (van Swet et al., 2011, p.909).

The medical model implies that the disability is within the individual and needs "fixing". This has led to specialisations in support services. It has also led to some teachers to believe that they are not sufficiently skilled to teach these students as the focus is on individual deficits (Slee, 2009). 
However, for the purposes of inclusion, the use of a medical model of disability categorisation is only part of the problem. More of concern is how education systems, schools and teachers use this information and how it impacts on the way that students are taught. Also of concern is the perpetuation of the belief systems which underpin the acceptance of the use of these labels for educational purposes (Erten and Savage, 2012).

In NSW a range of placement options is available. One option for students with disabilities is to be educated in special schools and this is especially true of some groups of students such as those with Profound Intellectual and Multiple Disabilities. According to Lyons and Arthur-Kelly: Although some national and state jurisdictions have taken the initiative to deliver educational services under one (authentically) inclusive milieu (e.g. Finland), "special education" and its infrastructure prevails. Most students with PIMD have an individualised needsbased teaching/learning program delivered in accordance with their Individualised Education Plan but this often relates little to the "common" curriculum mandated for the vast majority of students (Lyons and Arthur-Kelly, 2014, p.449).

Another option is attending a support class in regular schools, sometimes with partial integration into mainstream or regular classes for some subjects. In the 1980s and 1990s such placement was not necessarily accompanied by any changes to the pedagogy, the school environment or the existing belief system about students with disabilities. The attempt was to create as little disruption to the functioning of the class as possible (Anderson, Klassen, and Georgiou, 2007).

The thinking behind such placement is in contrast to the social model propounded by DEC currently: The social model accepts, in contrast to the medical model, the possible disability or problem is the result of the relationship of the pupil and his environment, in this case the school. One assumes that a disability can certainly lead to functional limitations but, in the end, it is the responsibility of society to see that the individual does not experience the limitation as a handicap (van Swet et al., 2011, p.910).

Most students with disabilities in NSW are educated in regular classes in regular schools with varying levels of support. NSW teachers have experienced a steep learning curve and have had to re-think their classroom practices driven on by the fact that The Board of Studies, Teaching and Educational Standards (BOSTES) which prescribes the key learning areas for all schools, state and private in NSW, has incorporated curriculum adjustments for students with disabilities as something which occurs within the mainstream curricula. Similarly, the DEC has adopted a social model with respect to disability. The handicap or difficulty is no longer seen as belonging exclusively to the student but rather as something that reflects the interaction between the student and his/her environment and the specific barriers that he/she may meet: physical; 
attitudinal; communication and social. Thus the environments need to change so that students with disabilities can participate on an equal basis with others.

\section{Teacher beliefs and professional learning}

The DEC is attempting to combat the impact of traditions and associated teacher beliefs through professional learning. Running parallel to the introduction of a social model was the introduction of the concept of quality teaching. This asked teachers to re-think what was important in the classroom: The core business of the profession of teaching is pedagog. Crucially, the term pedagogy recognises that how one teaches is inseparable from what one teaches, from what and how one assesses and from how one learns. The NSW Department of Education and Training is committed to providing a public school system, which develops fully the talents and capacities of all students in the pursuit of attaining the highest educational standards irrespective of students' background or circumstance (NSW, Department of Education and Training, 2003, p.4).

This meant a focus on the quality of each student's learning experience. Teachers had to reflect on relationships and connectedness in the classroom as part of the process of ensuring that learning was rigorous, meaningful and dignified for all students. DEC, while still relying on medical diagnoses for some disabilities, was moving towards personalised learning and support. The DEC was moving closer to the assumption expressed by Hulgin and Drake "that teaching is shaped by the particular needs, experiences and interests of a community of learners. The curriculum does not dictate who belongs" (Hulgin \& Drake, 2011, p.393).

Skrtic (Skrtic, 1991) states that change needs the involvement of those who have been marginalised. The needs of a diverse population of students are more likely to be met byschools that are 'adhocratic'. In such schools educators, students, families and community members are involved in collaborative processes benefiting from a sharing of expertise. Teachers need to re-examine their practices and move on from seeing the students as the ones with the problem just because they don't fit into the way their classes are currently organised. Belief systems need to change.

Reflecting the above thinking, in 2012, the DEC introduced a learning and support framework to embed personalised learning and support for any student with special needs. This was the "Every Student, Every School" initiative. This initiative aimed to provide better learning support for students whose learning was impacted upon by disability.

Personalised learning and support has four elements: collaboration; assessed individual need; adjustments and the impact of adjustments and is solution-focussed. As van Swet et al., point out "the concept of using a solutionfocused approach in an assessment process widens the prospect of potential 
results" (van Swet et al., 2011, p.920) and as ready made solutions don't exist, it leads the teacher to work in a reflective manner collaborating with parents, students, school personnel, peers and outside providers in order to determine learning needs and address these needs.

Another element is that of assessment. Each student is assessed to determine his or her individual needs Based on this adjustment are made which are changes to curriculum, instruction and environments that are personalised against each student's assessed need. Finally the impact of the adjustments needs to be determined. Evidence is collected, analysed and interpreted in order to make a judgement about the value of the adjustments. This information informs further actions. As van Swet et al. state, this means that: Diagnosis is no longer only conducted by individuals specifically trained for this purpose but, rather, within a cooperative network of teaching colleagues, parents, other professionals, organisations and the students themselves. This shifting assessment concept recognises the complexity of cognitive development and the need for many voices to understand challenges presented by individual learners (van Swet et al., 2011, p.911).

However even with a collaborative approach, the understanding and attitudes of the teacher play an important part in determining whether students with disabilities are actually included, as opposed to tolerated, in regular settings. As Hansen states: It is primarily the teacher who draws the line between inclusion and exclusion in the specific classroom. ... we should examine how the teacher constructs categories, teaching and classroom, because it is these constructions which decide the boundary between inclusion and exclusion (Hansen, 2012, p.95).

Most research shows that the successful introduction of reforms is directly related to the implementation strategies used by teachers and their knowledge, skills, attitudes, beliefs and ability to collaborate (Florian, 2005, 2007, 2008; Ainscow, 2003, 2004).

With its "Every Student, Every School" the DEC utilizes professional learning practice to impact upon school culture and practice. It provides a range of professional learning options to support teacher learning about students with disabilities. These include 9 modules detailing the "Every Student, Every School" initiative as well as individual e-learning opportunities for teachers across a range of topics such as: understanding autism spectrum disorder; understanding and managing behaviour; Inclusion of learners with speech, languages and communication needs; understanding dyslexia and significant difficulties in reading; understanding co-ordination difficulties. It also funds places in post-graduate special education courses at a Masters level. Additional professional learning is organised by schools as all schools are required to have incorporated professional learning into their school plan and, as a result, schools will organizeactivities which meet theirspecific needs. As Ainscow and Sandill state: ...the starting point must be with staff members: in effect, enlarging their 
capacity to imagine what might be achieved, and increasing their sense of accountability for bringing this about. This may also involve tackling taken for granted assumptions, most often relating to expectations about certain groups of students, their capabilities and behaviours (Ainscow \& Sandill (2010).

\section{From inclusion to every student}

DEC developed a multi-faceted approach in its attempts to make schools more inclusive. In 2012 three strategies came into operation: Connected Communities (targeting inclusion of Aboriginal students); Early Action for Success (implementation of the state's literacy and numeracy plan) and Local Schools, Local Decisions (an education reform that gave NSW public schools more authority to make local decisions about how best to meet the needs of their students).

The introduction of "Every Student, Every School" was accompanied, in 2013, by structural change. 1800 Learning and Support Teachers were allocated to schools, which was partially achieved by restructuring the existing itinerant teacher program. Learning and Support Teachers work collaboratively with classroom teacher to support students with disabilities. Flexible funding to support students with disabilities was also made available to every regular school. In 2014 the use of Personalised learning and support was enhanced through professional learning including Disability Standards e-learning $(47,550$ courses) and tutor supported online learning (24,000 courses).

From 2015 each school becomes accountable for its actions as it becomes mandatory to take part in national disability data collection (National Consistent Collection of Data, NCCD) using evidence of personalised learning and support. Interestingly it is based on the professional judgement of teachers about their students.

"Every Student, Every School" marks the DEC's move away from use of the term inclusion. Whilst the majority of students with disabilities in NSW receive their education in regular schools, this move has validated the existence of special schools as well, as it refers to every school not specifically regular schools. It is an acknowledgement of the confusion surrounding inclusive schooling as jurisdictions try to make sense of it with respect to their circumstances and needs. The focus on every student and every school challenges all teachers and leaders to re-think how learning occurs but it also includes various supports: professional learning; support in the regular classroom; special schools as centres of expertise; materials to meet additional learning needs and information to support teaching and learning as well as access to expert support. "Every student, Every School" provides clear direction rather than the uncertainty and misunderstandings that can arise in discussions of inclusion. It has a strong focus on acknowledging and celebrating diversity, of accepting that the students with disabilities also contribute to the class 
environment rather the being the outsider, the one with a label, and this is being used to confront existing teacher beliefs about students with disabilities.

\section{Conclusion}

The beginning of the inclusive schooling process in Latvia and NSW starts with legislature. Both education systems have developed policy documents and plans, and instituted mandatory requirements as a way to turn legislature into practice. The process of realising this legislature has led NSW to move from discussions of inclusion to ones that re-iterate the rights of each and every school student to quality education. However implementing change is an ongoing process and DEC is focusing on the professional learning of its teachers and school leaders as a crucial step in the process of confronting accepted beliefs and traditions. It has also modified to the way that students with disabilities are assessed, placed and their progress monitored and provided additional supports to regular schools as a way of reducing the gap in thinking between special education and inclusive education. In NSW the process of inclusion is framed within the concept of celebrating diversity. The experiences of both systems reflect the challenge that understanding and implementing inclusive education sets for education systems.

\section{References}

Aikman, S., \& Dyer, C. (2012). Education and inclusion: re-examining the narratives, Compare: A Journal of Comparative and International Education, 42(2), 177-185, DOI: $10.1080 / 03057925.2012 .652816$

Ainscow, M. (2003). Using teacher development to foster inclusive classrooms. In T. Booth, K. Nes, \& M. Stromstad (Eds.), Developing inclusive teacher education. London: RoutlendeFalmer. p. $15-32$.

Ainscow, M. (2004). Special needs through school improvement: school improvement through special needs. In D. Mitchell (Eds.), Special educational needs and inclusive education: major themes in education. Volume II Inclusive education. New York: Routlende Falmer, p.265 - 279.

Ainscow, M., \&Sandill, A. (2010). Developing inclusive education systems: the role of organisational cultures and leadership, International Journal of Inclusive Education, 14(4), 401-416, DOI: 10.1080/13603110802504903

Anderson, C.J.K., Klassen, R.M., Georgiou, G.K.(2007). Inclusion in Australia: What teachers say they need and what school psychologists can offer. School Psychology International 28, no. 2: 131-47.

Central Statistical Bureau of Latvia data. Retrieved from http://www.csb.gov.lv/statistikastemas/metodologija/iedzivotaju-skaits-un-galvenie-demografiskie-raditaji-36803.html

Erten, O., \& Savage, R.S. (2012). Moving forward in inclusive education research, International Journal of Inclusive Education, 16(2), 221-233, DOI: $10.1080 / 13603111003777496$

Florian, L. (2005). Inclusive practice: what, why and how? / Topping K. and Maloney S.(Eds.) The Routledge/Falmer Reader in Inclusive Education, London: Routledge/Falmer, p. $29-40$. 
Florian, L. (2007). The SAGE Handbook of Special Education, British Library, Cataloguing in Publication data.

Florian, L. (2008). Special or inclusive education: future trends. British Journal of Special Education, 35(4), p. $202-208$.

General Education Law (1999). Retrieved from www.ndg.lv/latvian/.../Visparejas\% 20izglitibas\%20likums.doc

Hansen, J. H.(2012). Limits to inclusion, International Journal of Inclusive Education, 16(1), 89-98, DOI: 10.1080/13603111003671632

Hulgin, K.M., \& Drake, B.M.(2011). Inclusive education and the No Child Left Behind Act: resisting entrenchment, International Journal of Inclusive Education, 15(4), 389-404, DOI: $10.1080 / 13603110903030105$

IZM Statistics and Data Analysis Division. Retrieved from http://izm.izm.gov.lv/registristatistika/statistika-vispareja/6281.html

Kavale, K.A., \& Forness, S. R. (2000). History, rhetoric, and reality: Analysis of inclusion debate. Remedial and Special Education,21(5), 279-296.

Lindsay, G. (2007). Annual review: Educational psychology and the effectiveness of inclusive education/mainstreaming. British Journal of Educational Psychology, 77, 1-24.

Lyons, G., \& Arthur-Kelly, M. (2014). UNESCO Inclusion Policy and the Education of School Students with Profound Intellectual and Multiple Disabilities: Where to Now? Creative Education, 5, 445-456.http://dx.doi.org/10.4236/ce.2014.57054

Miles, S. \& Singal, N. (2010). The Education for All and inclusive education debate: conflict, contradiction or opportunity. International Journal of Inclusive Education, 14(1),1-15.

NSW. Department of Education and Communities. (2011). Educational services supporting students with disabilities, 2011. Retrieved from http://www.schools.nsw.edu.au/media/ downloads/schoolsweb/stsupport/programs/disabilitypgrms

NSW. Department of Education and Communities. (2012). Every Student, Every School: Learning and Support. Retrieved from https:/www.det.nsw.edu.au/media/downloads/ about-us/how-we-operate/national-partnerships-program/every-student-every-school

NSW. Department of Education and Training. (2003). Qhality teaching in NSW public schools. Retrieved from http://www.det.nsw.edu.au/proflearn/docs/pdf/qt

Prudnikova, I. (2012). The development of practical activities experience for pupils with moderate and severe intellectual disabilities at special primary boarding school. Rezekne: Rezeknes Augstskola

Skrtic, T.M. (1991). Behind special education: A critical analysis of professional culture and school organization. Denver, CO: Love.

Slee, R. (2009). Beyond special and regular schooling?An inclusive education.International Studies in Sociology of Education,18,99-166.Van Swet, J., Wichers-Bots, J., \& Brown, K. (2011) Solution focused assessment: rethinking labels to support inclusive education, International Journal of Inclusive Education, 15(9), 909-923.

The Children's Rights Defence Law. (1998). Retrieved from http://www.likumi.lv/ doc.php?id=49096

The Education Act (1998). Retrieved from http://www.likumi.lv/doc. php?id=50759

The Education Development Guidelines for 2014 - 2020. Retrieved from www.mk.gov.lv/lv/mk/tap/?pid=40305684

The Latvian Constitution of the Republic. (1922/2010). Retrieved from http://likumi.lv/doc.php?id=

The Salamanca Statement and Framework for Action on Special Needs Education (1994). Retrieved from http://www.ecdgroup.com/docs/Salamanca_Statement_and_ Framework_for_Action_on_Special_Needs_Education-16_05_2001-09_20_08.pdf 
Van Swet et al (2011). Solution-focused assessment: rethinking labels to support inclusive education. International Journal of Inclusive Education, 15(9), 909-923, DOI: $10.1080 / 13603110903456615$

Villa, R., Thousand, J., Stainback, W., \&Stainback, S. (1992). Restructuring for caring andeffective education. Baltimore, MD: Paul H. Brookes. 